\title{
KOŽENÉ ARTEFAKTY Z ČESKÉ ULICE V BRNĚ
}

\author{
ALEŠ HOCH - PAVEL STANĚK
}

\begin{abstract}
Abstrakt: Článek se zabývá koženými artefakty pocházejícimi ze zásypů několika zaniklých jímek odkrytých v centru města Brna. V souboru, který čitá necelých tři sta nálezů, jsou téměr výhradně zastoupeny různé části obuvi. Ty bylo možné ve výjimečných připadech přriradit k sobě, ve dvou dokonce zkompletovat téměr do původního celku. Přvéźžnou část však tvoři neidentifikovatelné fragmenty, často ve velmi špatném stavu. Celý soubor tedy tvoři záměrně vyhozený odpad, část z něj pravděpodobně př́mo z ševcovské dilny. Pomocí dendrochronologie je datován do rozmezi 13. až 15. století.
\end{abstract}

Klíčová slova: Brno - vrcholný středověk - odpadni jímky - kožené artefakty - obuv.

\section{Leather Artefacts from Česká Street, Brno}

Abstract: This article discusses leather artefacts from the fills of several defunct refuse pits excavated in the centre of Brno. The series comprises nearly three hundred items, almost exclusively different parts of footwear. In some exceptional cases these could be matched, and in two cases they even made almost a complete shoe. The major part of the series consists of unidentifiable fragments, often in very bad repair. The series can be defined as disposed-of waste, partially probably from a shoemaker's workshop. It is dated by means of dendrochronology to the period between the 13th and 15th centuries.

Key words: Brno - high Middle Ages - refuse pits - leather artefacts - footwear.

\section{1 Úvod}

Analyzovaný soubor kožených předmětů byl nalezen během záchranného archeologického výzkumu na parcele pavlačového domu Česká 6, tzv. paláce Chlumeckých, který procházel v letech 2012 až 2014 kompletní rekonstrukcí a částečnou přestavbou. Hlavní část výzkumu byla prováděna od září 2012 do února 2013 společností Archaia Brno, o.p. s. Palác Chlumeckých byl postaven na konci 50 . let 19. století na parcelách přinejmenším tř́ až čtyř starších domů v nároží ulic České a Jakubské (Flodrová 2015, 127). Tato městiště se nacházela severně od náměstí Svobody v druhé brněnské čtvrti Quartale Letorum, kam na počátku 13. století v době konstituování města Brna přicházeli kolonisté označovaní jako „Teutonici, Gallici a Romani“, kteří se usazovali poblíž farního kostela sv. Jakuba a jeho filiálního kostela sv. Mikuláše (Procházka 2000, 133; Jan-Procházka 2013; Flodrová 2015, 124). Přri rekonstrukci podoby města Brna ve středověku provedené Oldřichem Vičarem dostaly sledované domy do ulice České čísla 81, 83, 86 a v ulici Jakubské 80 (1965, 263 a přiložený rekonstrukční plán). Na základě berních rejstř́íků a pamětních knih známe některé vlastníky zkoumaných parcel již pro 14. století (Flodrová 2015). V našem případě jsou nejzajímavější zmínky o ševcích či příbuzných řemeslnících, jejichž práce se mohla odrazit na skladbě zkoumaného souboru. Nejstarší písemné zmínky dokládají př́tomnost kožešníka v domě 83, který vlastnil v roce 1343 Jeno de Zebrawitz. V podnájmu u něho bydlel vedle pícníka Eczla kožešník Sidlin (Flodrová 2015, 133). Dům v Jakubské ulici Vičarem označený číslem 80 patřil v letech 1345-1348 zvoníku Jescovi, u kterého byly v roce 1348 zaznamenáni dva podnájemníci - Nicolaus de Schirnabicz a švec či podeševkraječ Nicolaus. K roku 1365 se v uvedených místech vyskytoval další švec, který se také jmenoval Mikuláš a označován byl jako Nicolaus parvus. Vlastnil však větší pozemek, než jak byl zaznamenán v předchozím období, a tak se hypoteticky uvažuje o spojení parcely č. 80 a rohové parcely 81 , která ve 40. letech patřila cihláŕi Henslinovi (Flodrová 2015, 137).

\section{Nálezová situace}

Zkoumaný soubor pochází z výplní celkem sedmi objektů interpretovaných jako jímky (obr. 1). Dochování předmětů z organických materiálů v nich umožnilo stálé vlhké prostředí. Do 


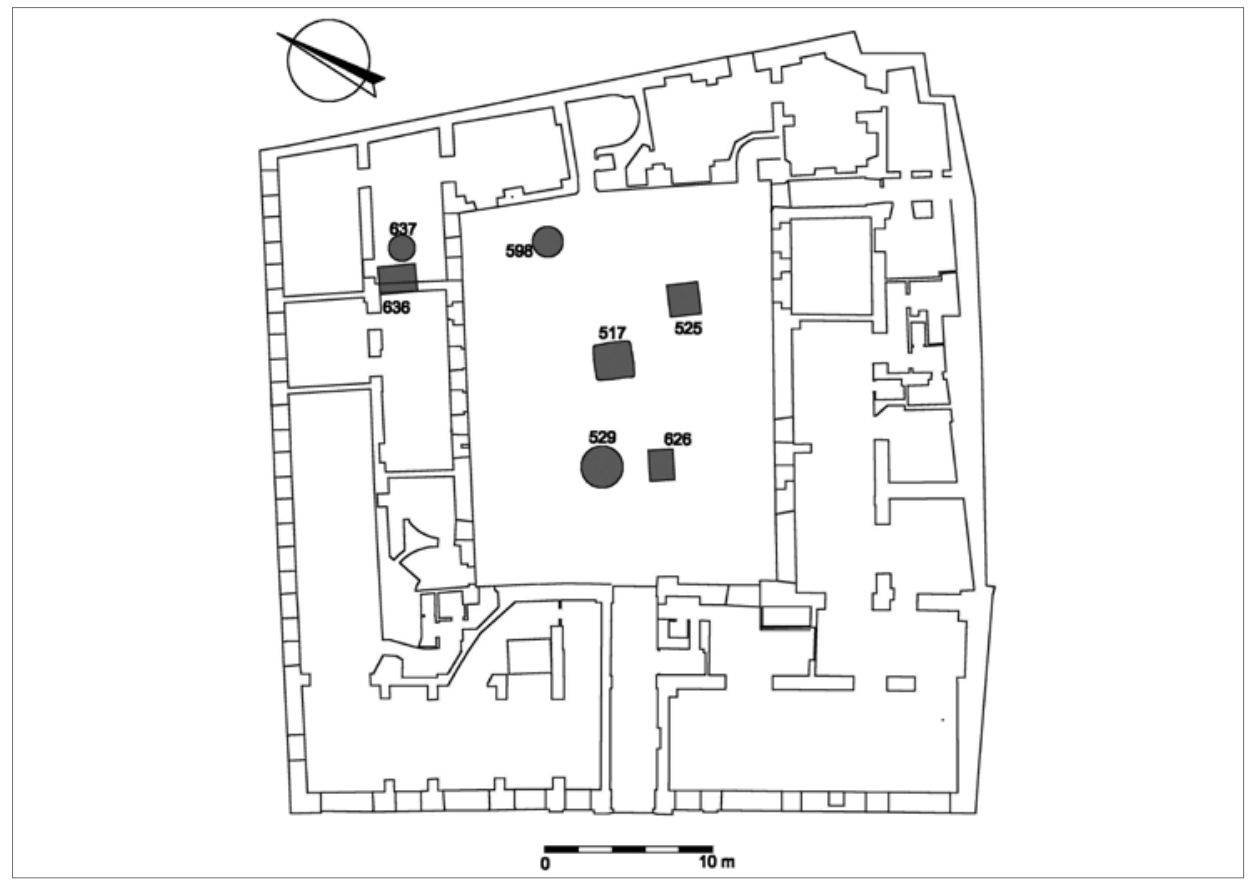

Obr. 1. Brno, Česká ulice. Plán plochy s vyznačením zkoumaných jímek. Zdroj archiv Archaia Brno, o.p.s.

Abb. 1. Brno, Česká-Straße. Flächenplan mit eingezeichneten untersuchten Abwasserbecken. Quelle Archiv der gemeinnützigen Gesellschaft Archaia Brno.

13. století lze zařadit jímky s. j. 525 a 637. Na dně prvně zmíněné leželo pohozené prkno vyrobené z jedle, která byla dle dendrochronologického určení Tomáše Kyncla skácena na přelomu let 1230 a 1231. Do 14. století lze zařadit kruhové jímky s. j. 598 a 529. Objekt s. j. 529 představoval původně kamennou studnu, která v druhé půli čtrnáctého století plnila funkci odpadní jímky. V jejích výplních se nalezlo značné množství dřevěných předmětů - především dýh ze skládaných z misek. K jejich výrobě bylo použito jedlové dřevo ze stromu skáceného po roce 1376 . Do 15. století náležela jímka s. j. 517, která porušovala starší jímku s. j. 520. Z její dřevěné konstrukce se zachoval trám, který je datován do roku 1441. Další jímka z uvedeného období byla opět vydřevena dubovými trámy, pokácenými v rozmezí let 1421-1438. Poslední analyzovaná jímka byla vydřevena dubovými kuláči, které byly pokáceny na přelomu let 1478 a 1479.

\section{Nálezový soubor}

Soubor kožených (resp. usňových) nálezů z České ulice čítá přibližně 280 artefaktů. Toto číslo však není přesné a reálný počet bude o něco nižší, nebot' se v něm nachází velké množství fragmentů, které původně patřily jednomu kusu. $Z$ tohoto celkového počtu bylo možné z hlediska funkce určit s různou mírou přesnosti ca 63 artefaktů. Dalších minimálně 20 artefaktů lze označit jako výrobní odpad (výkrojky) vzniklý zpracováním nových usní. Ve zbylých př́ípadech je sice výjimečně možné určit, z jakého předmětu fragment pochází, ale jinak jde veskrze o neurčitelný materiál, který lze vhledem k jeho bídné kvalitě dochování označit jednoznačně za odpad. Nejvíce takovýchto nálezů (ca 190) pochází z uloženiny s. j. 1157, která byla zachycena v jímce s. j. 637. Lze proto uvažovat o tom, že jde o doklad blízké přítomnosti ševcovské dílny. Jímka je však datována do 13. století a pro tuto dobu nemáme žádné písemné záznamy, které by mohly tuto domněnku potvrdit. Naopak výskyt ševce je zde písemnými prameny doložen v roce 1365. S tímto datem je hypoteticky možné spojit jímku označenou jako s. j. 529, datovanou po- 


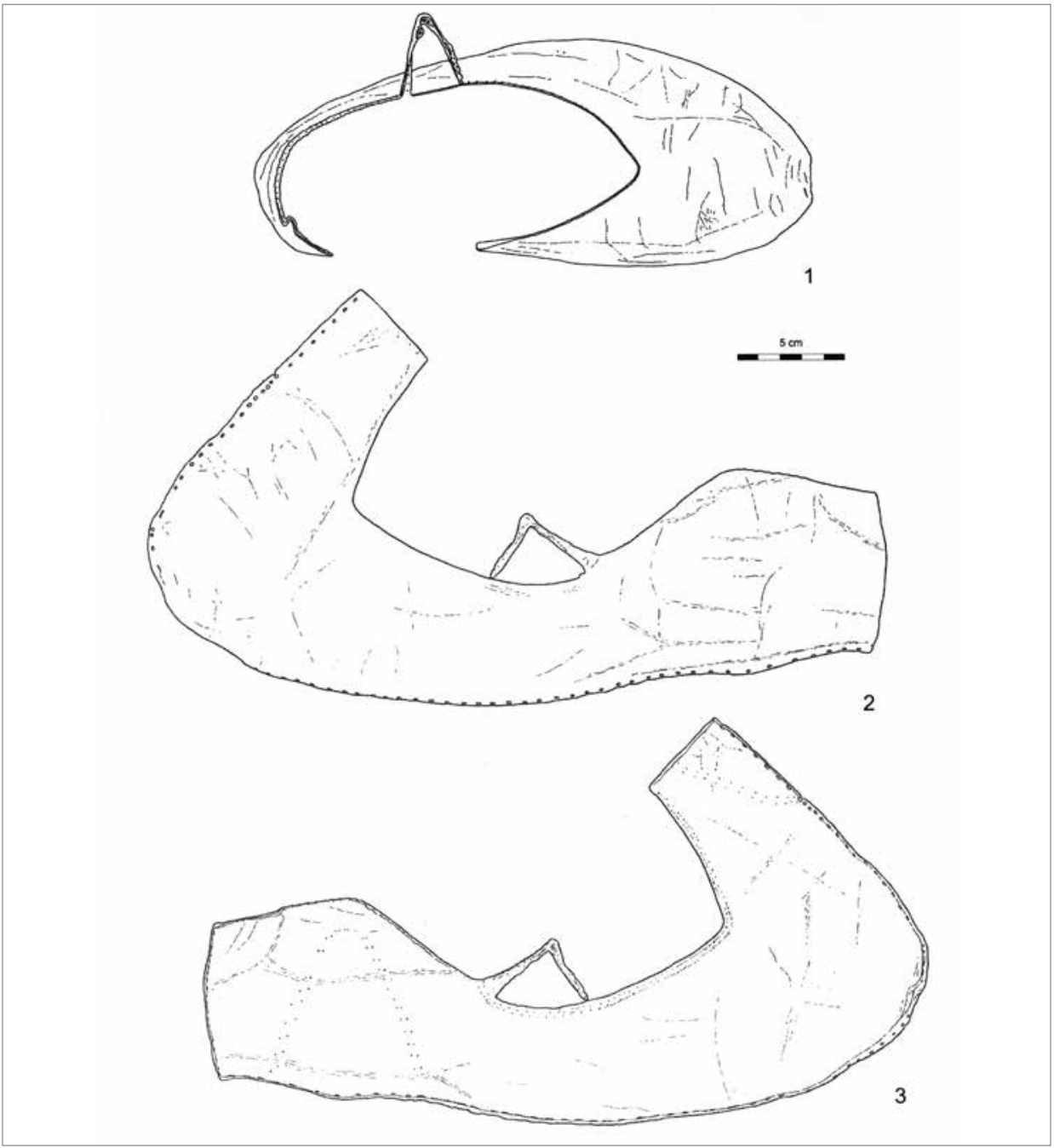

Tab. I. Svršek nízkého střevíce s páskem přes nárt. 1 - pohled shora, 2 - líc, 3 - rub. Kresba I. Ženožičková.

Taf. I. Schaft eines flachen Schuhs mit Ristriemen. 1 - Blick von oben, 2 - Außenseite, 3 - Innenseite. Zeichnung I. Ženožičková.

mocí artefaktů z výplně do roku 1376. Z této jímky pochází také jediný nález téměř kompletního půlpáru obuvi a další svrškové i spodkové dílce. Počet dalších artefaktů, zejména výrobního odpadu, je však minimální a tuto situaci tak nelze prokazatelně označit za doklad př́tomnosti ševcovské dílny.

Ke zpracování do předkládaného článku byly vybrány pouze nejzajímavější kusy s největší výpovědní hodnotou ze skupiny identifikovatelných artefaktů. U některých bylo také provedeno určení použitého materiálu, často bohužel bez pozitivního výsledku. Pro lepší přehled byly tyto nálezy rozděleny do funkčních skupin, resp. podskupin. ${ }^{1}$

1 Rozdělení do podskupin je nutné zejména u obuvi. Každá bota (resp. půlpár obuvi) se i dnes skládá z několika částí, ze kterých se však ve středověku použivaly jen některé. Základními jsou spodkové dílce (podešev, příp. těsnicí pásek tzv. okolek) a svrškové dillce (předni a zadní, prííp. podšivka a lemůvka). Dalšími zástupci jsou dillce opravné (např. podrážka). Speciální součástí svršku obuvi jsou dílce ztužovací. Ty mají za úkol držet tvar obuvi a chránit nohu před ostrými nebo tvrdými předměty. Na středověké obuvi je doložen zejména opatek, umístěný v oblasti paty, méně již boček a také podkroužek, který se uživá ve šněrovací části. Zcela výjimečně se pak vyskytne i výztuha v oblasti špice, tzv. tužinka (Floriánová 2005, 119-120; Zeman-Potůček 1965, 62-76). 

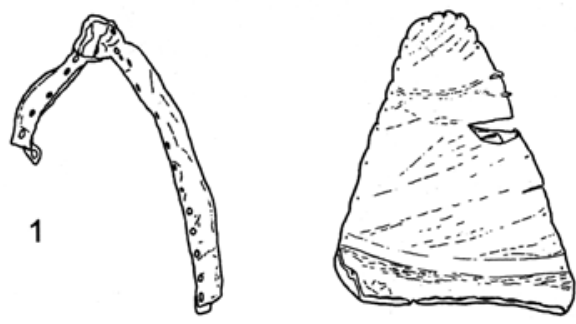

2
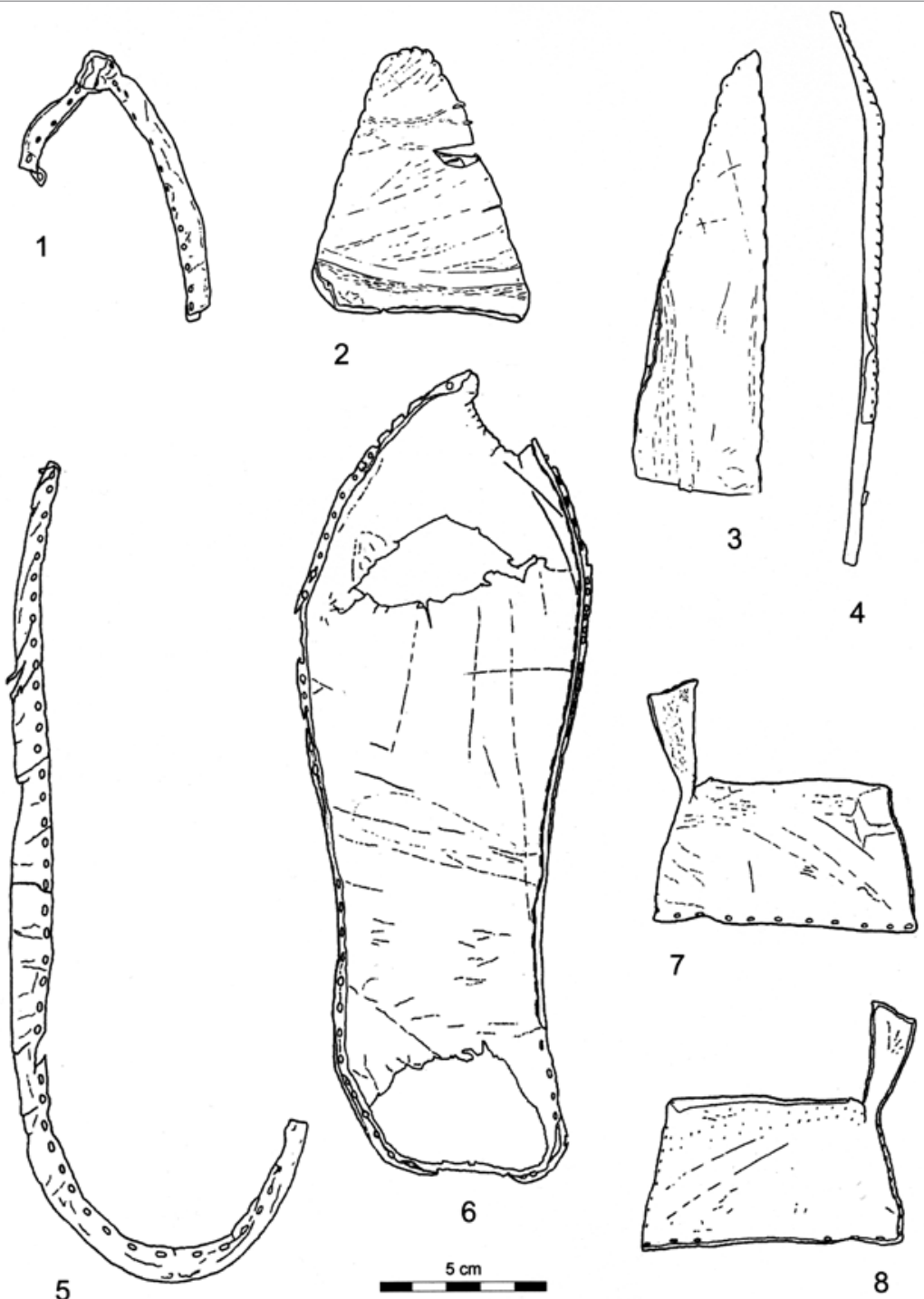

Tab. II. Dílce z nízkého stř̌evíce s páskem přes nárt. 1 - okolek (špice), 2 - opatek, 3 - boček, 4 - lemůvka, 5 - okolek, 6 - podešev, 7 - nástavný dílec svršku (líc), 8 - nástavný dílec svršku (rub). Kresba I. Ženožičková.

Taf. II. Teilstücke eines flachen Schuhs mit Ristriemen. 1 - Rahmen (Spitze), 2 - Absatz, 3 - Seitenteilstück, 4 - Bordüre, 5 - Rahmen, 6 - Sohle, 7 - Verlängerungsteilstück des Schaftes, (Außenseite), 8 - Verlängerungsteilstück des Schaftes (Innenseite). Zeichnung I. Ženožičková.

\section{$3.1 \mathrm{Obuv}$}

Tato skupina nálezů v celém souboru jednoznačně dominuje, náleží sem celkem 61 identifikovatelných předmětů a další nespecifikované množství z druhé skupiny (drobné útržky z rozpadlých dílců).

Nejzajímavějším a na české poměry vzácným nálezem je téměř kompletní půlpár nízké kotníkové obuvi, který však nebyl vyzvednut vcelku, ale v podobě několika samostatných dílců (tab. I, II). Je však jisté, že byl původně vyhozen jako celek, přičemž k rozpadu nití, a tedy i ce- 
lého výrobku došlo až v jímce. Nález se skládá z původně trojdílného svršku, lemůvky zakončující horní obvodový okraj, podešve, pásku spojujícího svršek a podešev, tzv. okolku (sloužil k utěsnění švu a opravám) a dvou vnitřních vyztužovacích dílců, opatku a bočku. $Z$ původního celku schází jen jeden ze tř́i svrchních dílců, a to zapínací pásek na mediální straně a také přezka. Na základě dochovaných stop po šití na rubové straně je také vysoce pravděpodobné, že vnitřní komfort byl zvýšen textilní podšívkou. $V$ oblasti špice je patrná zajímavě řešená oprava protrženého místa. K zacelení vzniklé dírky byl použit okolek, který byl v této oblasti také

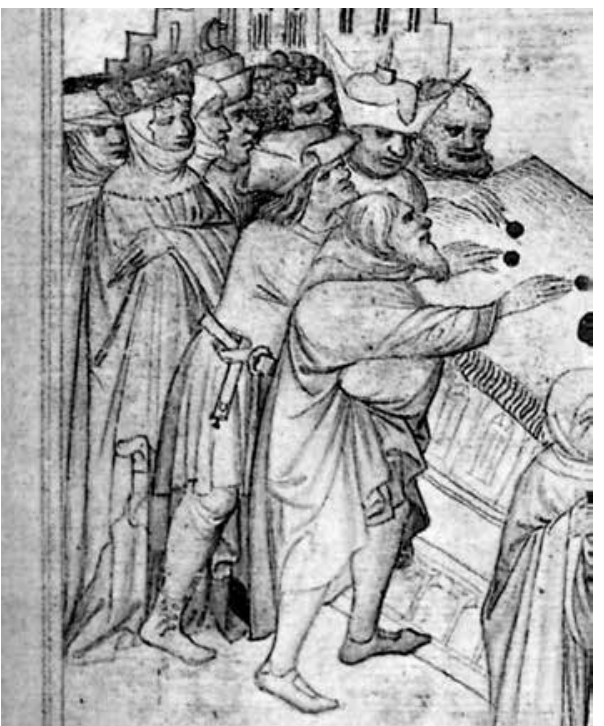

Obr. 2. Muž v popředí je obut v nízké střevíce s páskem přes nárt, muž za ním v polovysokou obuv se zapínáním pomocí kožených kolíčků (knoflíkủ) s ocáskem. Výjev z Mandevillových cest, polovina 14. století. Podle Krása 1990, 283.

Abb. 2. Der Mann im Vordergrund trägt flache Schuhe mit Ristriemen, der Mann hinter ihm Halbschuhe mit einem Knöpfriegelverschluss. Szene aus der Reisebeschreibung von Mandeville, Mitte 14. Jhdt. Nach Krása 1990, 283. zčásti vyměněn (jiný způsob prošití oproti stávajícímu). Maximální rozměry největšího (svrchního) dílce $\mathrm{v}$ rozloženém stavu činí $340 \times 180 \times 97$ mm, menší lichoběžníkovitý dílec má rozměry $80 \times 65 \times 45 \times 72 \mathrm{~mm}$ a část ozdobné lemůvky $160 \times 10 \mathrm{~mm}$. Použitá useň byla vyrobena z hovězí, či spíše telecí kủže.

Ze spodních dílců je zastoupena mírně asymetrická podešev, jejíž maximální rozměry činí ca $250 \mathrm{~mm}$ na délku, $92 \mathrm{~mm}$ v oblasti nártu, $64 \mathrm{~mm} \mathrm{v}$ poměrně nevýrazném klenku (středu) a ca $62 \mathrm{~mm} v$ patě. Podle současného číslování by tak šlo přibližně o dospělou velikost č. 37. Podešev je vyrobena $\mathrm{z}$ původně vcelku silné usně (ca $2 \mathrm{~mm}$ ), která je v současnosti již silně degradovaná (rozpadlá). Oproti svrškovým dílcům je značně poškozená (prochozená), a to zejména $v$ oblasti paty, prstních kloubů a špice, tedy v místech, kde přirozeně dochází $\mathrm{k}$ nejsilnějšímu kontaktu s chodidlem. Zajímavé však je, že zde nejsou patrné žádné snahy o opravu a podešev byla nošena až do př́íslovečného roztrhání, což kontrastuje s dobře zachovalým a krom špice nepoškozeným svrškem. Tento fakt má zřejmě zajímavé vysvětlení. Na největším ze svrškových dílců

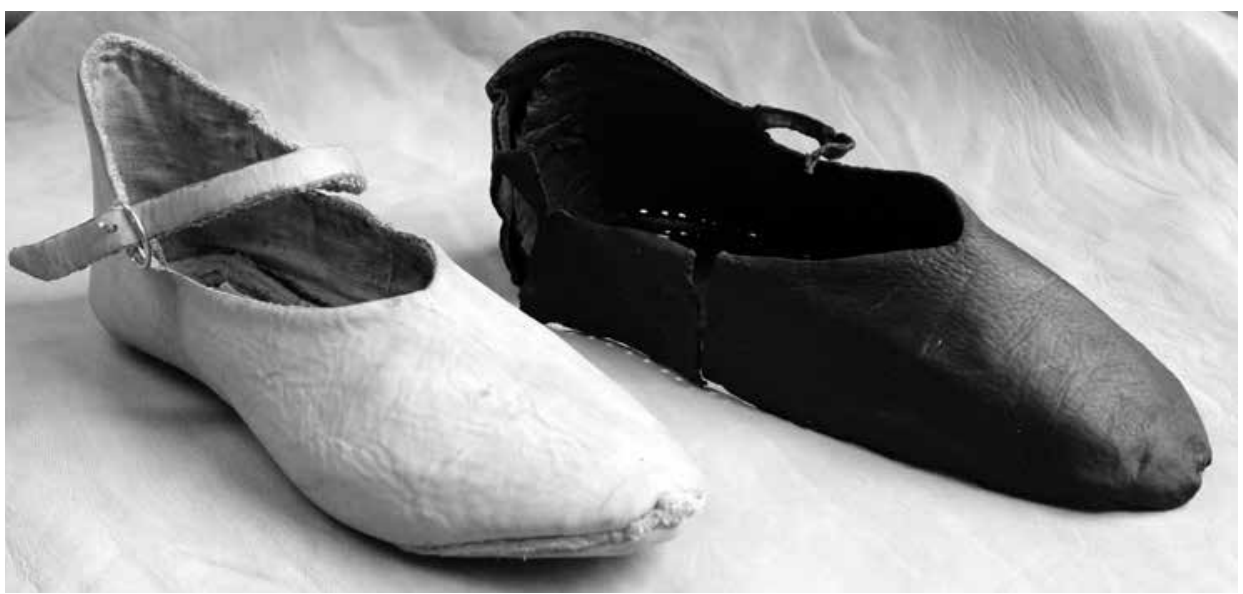

Obr. 3. Originál a replika nalezeného nízkého střevíce s páskem přes nárt a přezkou. Replika byla zhotovena v obuvnické dílně M. Horkého. Foto archiv Archaia Brno, o.p.s.

Abb. 3. Original und Replik eines gefundenen flachen Schuhs mit Ristriemen und Schnalle. Die Replik wurde in der Schuhmacherwerkstatt von M. Horký angefertigt. Foto Archiv der gemeinnützigen Gesellschaft Archaia Brno. 


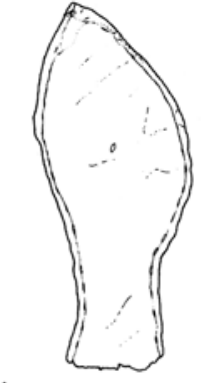

1

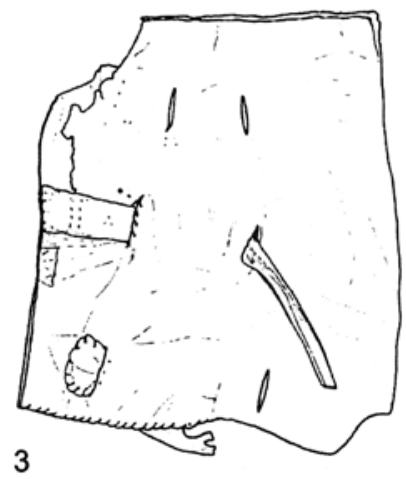

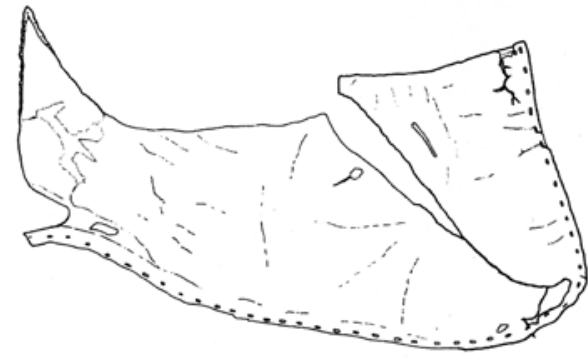

$5 \mathrm{~cm}$
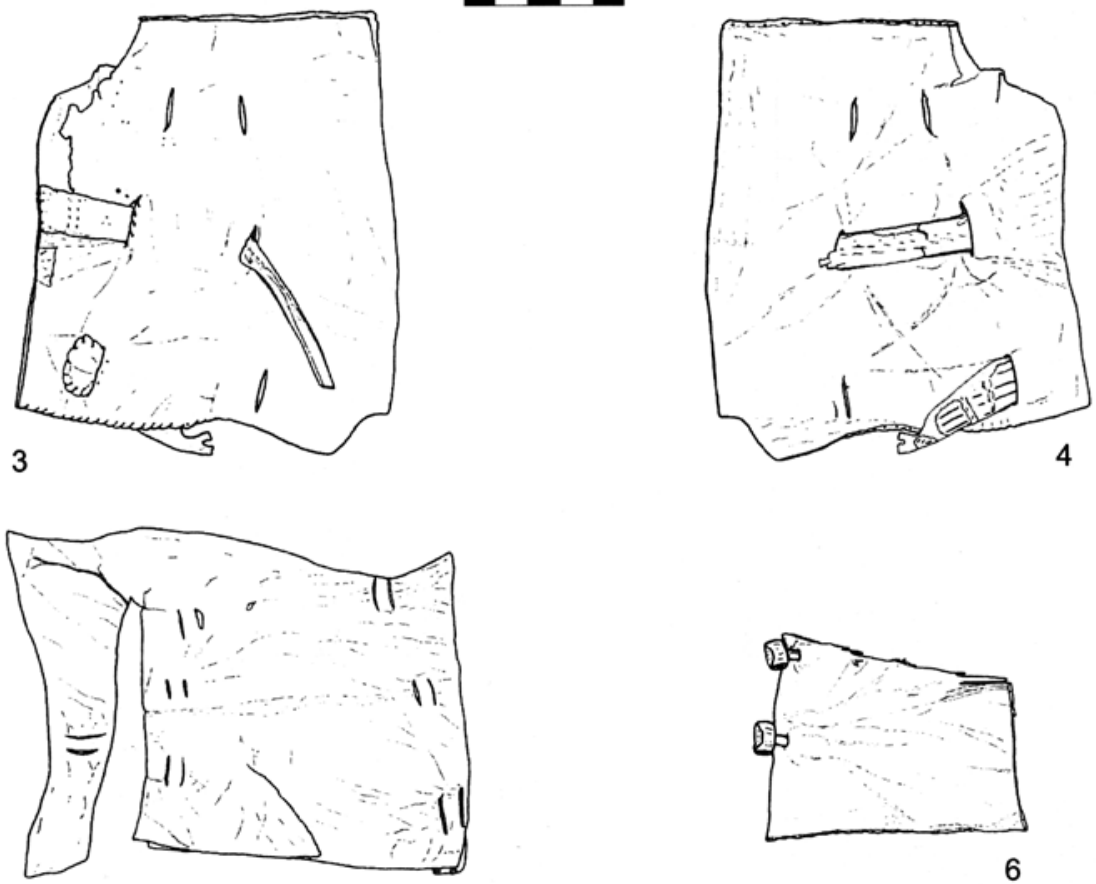

5

Tab. III. Dětská bota. 1 - podešev, 2 -svršek; svrškové dílce: 3 - dílec s ozdobně prosekávanými řemínky (rub), 4 - dílec s ozdobně prosekávanými řemínky (líc), 5 - dílec s párovými otvory pro zavazovací řemínky, 6 - dílec se zapínacími kolíčky. Kresba I. Ženožičková. Taf. III. Kinderschuh. 1 - Sohle, 2 - Schaft; Schaftteilstücke: 3 - Teil mit dekorativ durchstanzten Riemen (Innenseite), 4 - Teil mit dekorativ durchstanzten Riemen (Außenseite), 5 - Teil mit Schlitzpaaren für Schnürriemen, 6 - Teil mit Knöpfriegeln. Zeichnung I. Ženožičková.

byly před konzervací v nártové části dobře parné otlaky, způsobené klouby prstů a deformovaná (vypouklá) je také oblast paty. Na svrškových dílcích se však běžně otlaky od chodidla nedochovávají. $Z$ těchto indicií tak vyplývá, že minimálně tento půlpár byl svému nositeli pravděpodobně malý a po prošlapání podešve jej raději vyhodil. Vyloučit nelze ani vadu chodidla.

Ze spodkových dílců se dochovaly ještě nerovnoměrně vykrojené okolky o šířce 5 až $13 \mathrm{~mm}$, oba z poměrně silné usně. Jak již bylo řečeno výše, v oblasti špice byl jeden využit k opravě. Dosvědčuje to netypická změna prošití ze směru rub/hrana a také výrazně vykrojená 


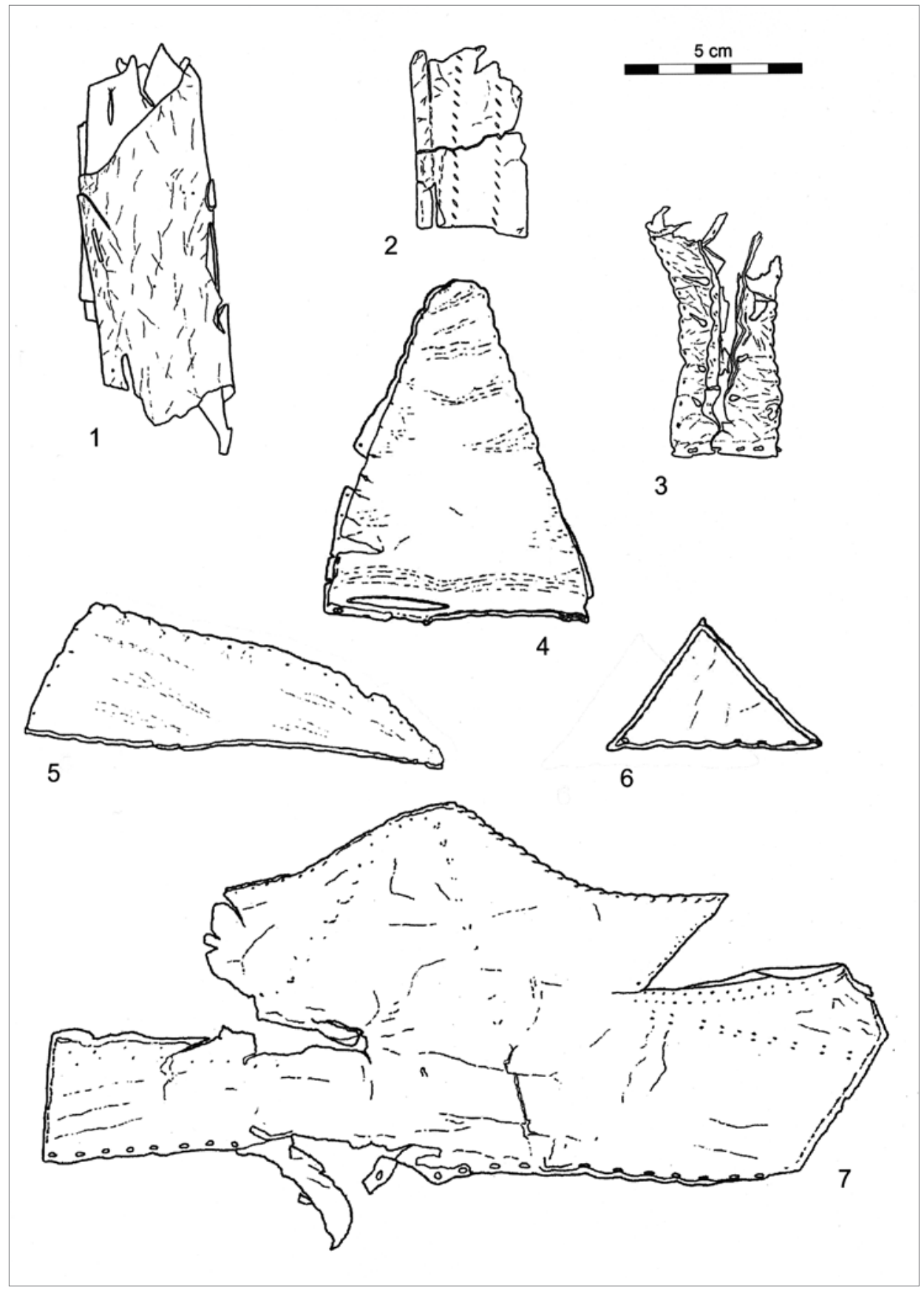

Tab. IV. Ostatní. 1 - pochva, 2 - opasek; vyztužovací dílce: 3 - podkroužek; dílce z nízké kotníkové boty: 4 - opatek, 5 - boček, 6 - nástavný dílec, 7 - zadní část svršku. Kresba I. Ženožičková.

Taf. IV. Sonstiges. 1 - Scheide, 2 - Gürtel; Versteifungsteilstücke: 3 - Futter; Teilstücke von flachen Knöchelschuhen: 4 - Absatz, 5 - Seitenteilstück, 6 - Verlängerungsteilstück, 7 - hinterer Teil des Schaftes. Zeichnung I. Ženožičková. 


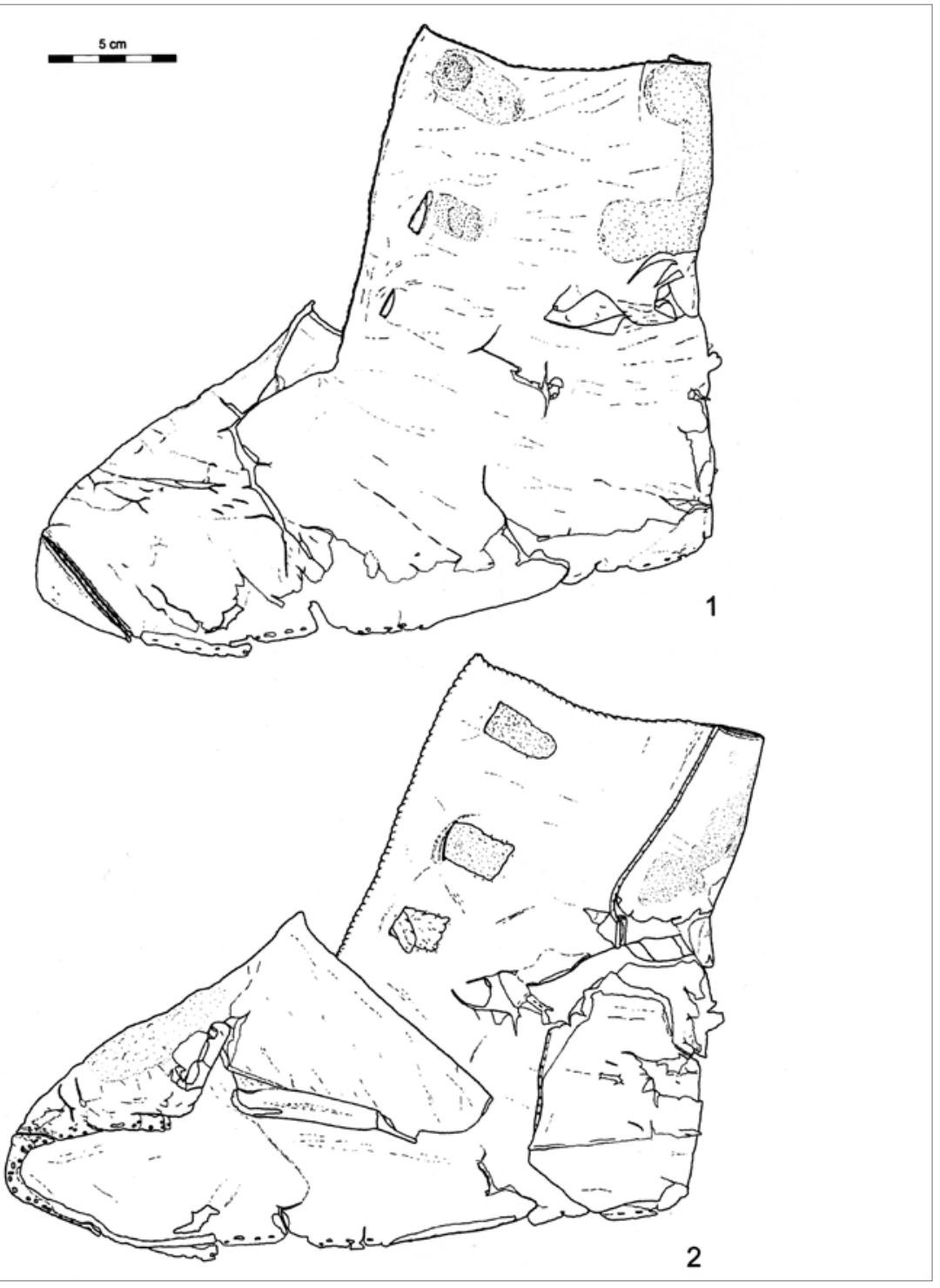

Tab. V. Svršek polovysoké boty. 1 - lícová strana s tužinkou ve špici, 2 - rubová strana se zbytky řemínků. Kresba I. Ženožičková. Taf. V. Schaft eines Halbschuhs. 1 - Außenseite mit Vorderkappe, 2 - Innenseite mit Riemenresten. Zeichnung I. Ženožičková.

špice, která přesně sedí na poškozené místo. Svrškové a spodkové dílce k sobě byly přišity standardními stehy vedenými ve směru rub/hrana (podešev) a rub/líc (svršek). ${ }^{2} \mathrm{~K}$ perforaci otvorů bylo použito kulaté či oválné šídlo.

Z hlediska technologie výroby jde o tzv. obrácenou obuv, z typologického pak náleží do skupiny definované $\mathrm{v}$ zahraniční literatuře přibližně jako otevřená obuv s páskem přes nárt (type 45, podle Goubitz 2001, 173-174), nebo taky jako otevřená nártová obuv s přezkou na nártu (SCD 29, typ Schlei, podle Volken 2014, 154-156, 207, 324). Tento typ se obecně vyskytuje

2 Ve shodě se zavedenou terminologií je uvedeno předpokládané místo vstupu a výstupu šídla (jehly). 


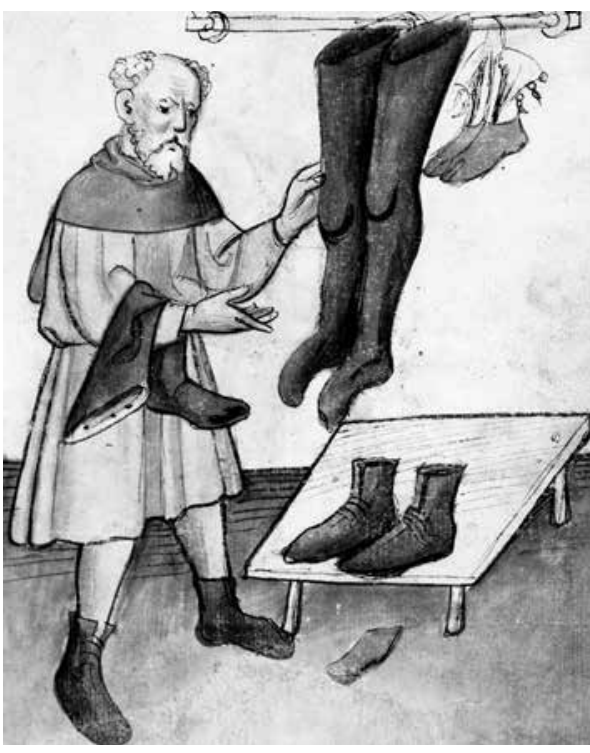

Obr. 4. Norimberský švec, 1425. Na vyobrazení můžeme vidět vysoké boty (holiny) a polovysokou obuv se zapínáním pomocí kožených kolíčků či pásků přes nárt. Podle Hausbuch der Mendelschen Zwölfbrüderstiftung, on-line.

Abb. 4. Nürnberger Schuster, 1425. Auf der Abbildung sind hohe Schuhe (Stiefel) und Halbschuhe mit Knöpfriegelverschluss bzw. Ristriemen zu sehen. Nach Hausbuch der Mendelschen Zwölfbrüderstiftung, on-line.

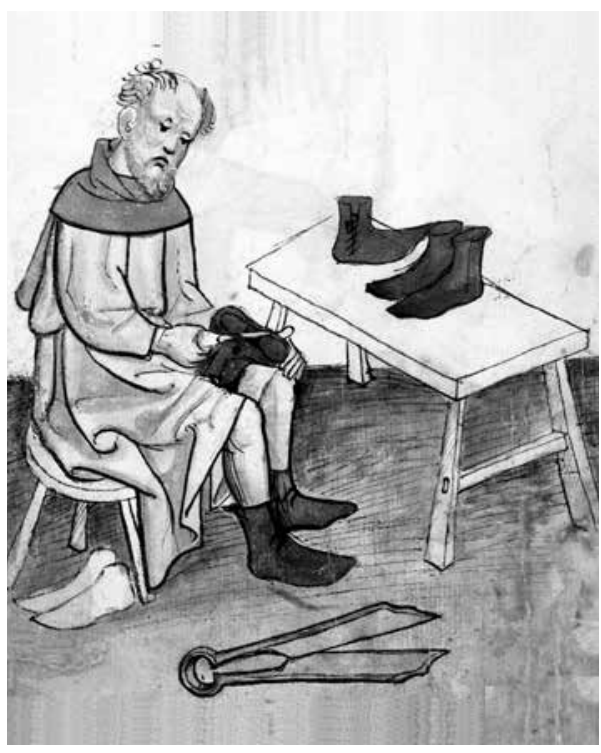

Obr. 5. Norimberský švec při práci, 1425. V zadní části stolu je vyobrazen půlpár polovysoké obuvi se zavazováním pomocí tkaniček umístěných na boku. Podle Hausbuch der Mendelschen Zwölfbrüderstiftung, on-line.

Abb. 5. Nürnberger Schuster bei der Arbeit, 1425. Im hinteren Teil des Tisches ist ein Halbschuh mit seitlichem Schnürverschluss zu sehen. Nach Hausbuch der Mendelschen Zwölfbrüderstiftung, on-line.

v západní Evropě a Polsku od konce 13. do 15. století (např. Wywrot-Wyszkowska 2009, 47, Ryc. 16-4; Schnack 1994, 26-27; Mould-Carlise-Cameron 2003, 3335 aj.). Běžně je k vidění také v ikonografických pramenech (obr. 2). Zkoumaný půlpár pochází ze zásypu jímky datované do roku 1376, což s uvedenými fakty plně koresponduje. Vzhledem k tomu, že byly k dispozici téměř všechny dílce, a také faktu, že jde o velice zajímavý, nikoliv zcela běžný nález, byla zhotovena jeho replika (obr. 3).

Také v pořadí druhý nález představuje částečně dochovaný pravý půlpár, tentokrát dětské obuvi. Jde o původně dvou- až třídílný svršek, ze kterého se dochoval největší dílec pokrývající nárt, pravý bok a část paty (tab. III, obr. 2). Maximální rozměry v rozloženém stavu činí $180 \times 120 \mathrm{~mm}$ a k výrobě byla použita useň z ovce či kozy. Ze spodkových dílců se dochovala necelá, výrazně asymetricky vykrojená podešev zakončená do poměrně ostré špice (tab. III, obr. 1). Vzhledem k tomu, že schází patní část, nelze stanovit celkový rozměr artefaktu. Současné maximální rozměry tak činí $115 \mathrm{~mm}$ na délku, $47 \mathrm{~mm}$ v oblasti nártu a $27 \mathrm{~mm}$ v klenku. Na rubové straně svršku jsou jasně patrné negativy po přišití vyztužovacích dílců, a to opatku a podkroužku. Obuv je kotníkového či nadkotníkového střihu a k noze se upínala pomocí jednoho řemínku zakončeného koženým kolíčkem (knoflíkem), po kterém se však dochoval pouze typický otvor ve tvaru klíčové střílny. Z typologického hlediska tak pravděpodobně jde o obuv se zapínáním pomocí kolíčku s ocáskem (type 75, podle Goubitz 2001, 201; SCD 28 podle Volken 2014, 152-153). Pozoruhodné je, že tento typ se v zahraničí z 95 \% vyskytuje pouze u dětské obuvi a svršek, stejně jako v tomto př́ípadě, téměř vždy zakrývá kotník. Datovat jej lze spolehlivě do 14.-15. století (Goubitz 2001, 201-204).

K dalším zajímavým nálezům patří dvě skupiny dílců ze zadních částí svršku. Obě pochází z obuvi nízkého kotníkového střihu s obloukovitě až špičatě vykrojenou patní částí. První skupinu tvoří část dílce s maximálními rozměry $235 \times 102 \mathrm{~mm}$, ke kterému náleží ještě malý ná- 

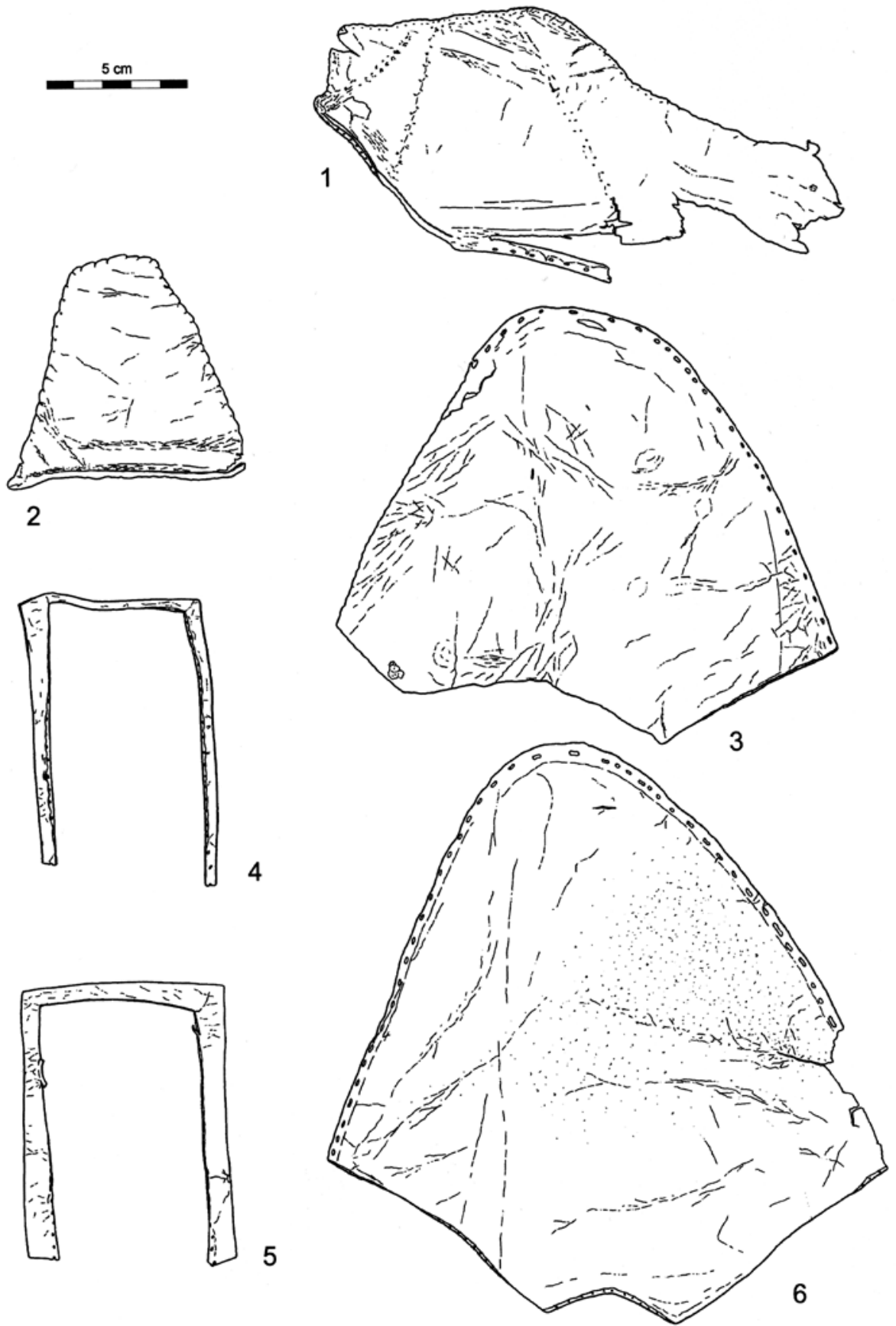

4

5

Tab. VI. Dílce z nízké kotníkové boty: 1 - zadní část, 2 - opatek; dílce z vysoké nazouvací obuvi (holinek): 3 - nártová část se špicí, 4 - odřezek z nártu, 5 - odřezek z nártu, 6 - nártová část se špicí. Kresba I. Ženožičková.

Taf. VI. Teilstücke von flachen Knöchelschuhen: 1 - hinterer Teil, 2 - Absatz; Teilstücke von hohen Schlupfschuhen (Stiefeln): 3 - Ristteil mit Spitze, 4 - Ristverschnitt, 5 - Ristverschnitt, 6 - Ristteil mit Spitze. Zeichnung I. Ženožičková. 
stavný dílec ve tvaru trojúhelníku o délce stran $62 \times 50 \times 42 \mathrm{~mm}$ (tab. IV, obr. 6, 7). Také v tomto prrípadě byl větší z dílců na horním okraji původně zkrášlen obšitím nebo lemůvkou. Dle dochovaných stop po šití zde byla použita také podšívka. Do této skupiny náleží ještě i boček a opatek (tab. IV, obr. 5, 4). Prvně jmenovaný má trojúhelníkovitý tvar o rozměrech $102 \times 100 \times 75 \mathrm{~mm}$, druhý přibližně také o délce stran $120 \times 112 \times 43 \mathrm{~mm}$.

Druhou skupinu tvoří opět pouze část dílce o maximálních rozměrech $182 \times 86 \mathrm{~mm}$, který taktéž nese na horním obvodovém okraji stopy po ozdobném obšití či našití lemůvky (tab. VI, obr. 1). Na rubové straně jsou také dobře patrné stehy po přišití vnitřních vyztužovacích dílců, bočku a opatku, který se dochoval také. Má přibližně lichoběžníkovitý tvar o délce stran $83 \times 80 \times 80 \times 30 \mathrm{~mm}$ (tab. VI, obr. 2). Ke spojení se spodkem bylo ve všech případech použito stehu ve směru rub/líc. Také u těchto dílců bylo provedeno druhové určení materiálu, které ukázalo, že na výrobu byla použita hovězí useň. Všechny dílce pochází z jímky označené jako s. j. 529, jejíž výplň je pomocí dendrochronologie datována do roku 1376.

\subsubsection{Svrškové dílce}

$\mathrm{V}$ následující kapitole budou uvedeny již jen jednotlivé dílce. $\mathrm{K}$ nejzajímavějším patří jednoznačně svršek polovysoké boty o maximálních rozměrech $337 \times 220 \mathrm{~mm}$ (tab. V). K jeho výrobě byla použita useň vyrobená $z$ hovězí kůže. Dílec je ve velice špatném stavu a $z$ tohoto důvodu byl patrně také vyhozen. Zajímavý je na něm především fakt, že byl pravděpodobně ušit bez vnitřních vyztužovacích dílců (absence stop po šití), což není př́iliš běžné. Naopak zpětně (již v době užívání) byla $\mathrm{z}$ vnější strany vyztužena (ne opravena!) špice pomocí tzv. tužinky. Takovýto zásah je velice netypický a nabízí různá vysvětlení. Nositel se např. mohl pohybovat v prostředí, kde hrozil úraz prstů apod. V oblasti prokrojení nártu se dochovaly tři pod sebe kladené otvory se zbytky zdvojených zapínacích řemínků. Ty byly našity na rubové straně a před vyhozením z větší části odříznuty. Vzhledem $\mathrm{k}$ faktu, že chybí protilehlá boční strana, nelze s jistotou říci, o jaký typ obuvi přesně jde. Zdvojení řemínkủ však napovídají, že by mohlo jít o jednu z forem se zavazovacími tkaničkami. Předmět pochází ze zásypu jímky, jejíž vznik je datován na přelom let 1230 a 1231 .

Následující fragment svrchního dílce o maximálních rozměrech $87 \times 72 \times 65 \times 46 \mathrm{~mm}$ lze z typologického hlediska vcelku dobře zařadit (tab. III, obr. 6). Díky přítomnosti dvou kožených kolíčků (knoflíků) je zřejmé, že pochází z obuvi zapínané jimi přes holeň či nárt (type 35, podle Goubitz 2001, 164; SCD 28 či 33, podle Volken 2014, 152-153, 165-167; obr. 2, 4). Dílec pochází z jímky datované do 40 . let 15 . století.

Pomocí minimálně tř́ řad řemínků s jednoduchým ozdobným prosekáváním byla k noze upevňována obuv, ze které pochází část dílce o maximálních rozměrech $140 \times 130 \times 118 \times 107 \mathrm{~mm}$ (tab. III, obr. 3, 4). Řemínky našité napevno k rubové straně naznačují, že by mohlo jít o obuv zapínanou pomocí přezek. Dílec pochází z jímky, jejíž vznik je datován do roku 1441.

Dvojité páry krátkých otvorů kladených ve třech řadách svědčí o přítomnosti dalšího typu obuvi, který byl k noze upevňován pomocí jednoho a více řad zavazovacích řemínků (type 10, podle Goubitz 2001, 135-136; SCD 23, podle Volken 2014, 140-141). Tento nekompletní dílec má maximální dochované rozměry $140 \times 105 \mathrm{~mm}$ a pochází z oblasti boku a prokrojení nártu (tab. III, obr. 5). V souboru lze nalézt ještě několik dalších fragmentů tohoto typu obuvi, které pochází z jímky datované do 30 . let 13. století. Právě ve 12. až 13. byla tato obuv značně oblíbená, vyskytuje se však i ve století následujícím (obr. 6). To ostatně dokazuje i tento konkrétní nález, jelikož pochází z jímky datované do 70 . let 14. století.

Posledními zástupci této skupiny jsou dva odřezky z oblasti nártu o maximálních rozměrech $96 \times 10 \mathrm{~mm}$ a $100 \times 12 \mathrm{~mm}$ (tab. VI, obr. 4, 5). Vnější obvodové hrany jsou v obou případech oříznuté, zato vnitřní jsou prošity stehem vedeným ve směru rub/hrana. Je tedy zřejmé, že zde byl našit či našity další dílce. S velkou pravděpodobností jde o následující dva nálezy, pocházející ze stejné uloženiny. Jsou to samostatné svršky z nártové části. První o maximálních rozměrech $192 \times 190 \mathrm{~mm}$ byl ke spodkovým dílcům přišitý standardním stehem vedeným ve směru rub/líc a ke svrškovým rub/hrana (tab. VI, obr. 6). Dílec je na první pohled v dobrém stavu, 


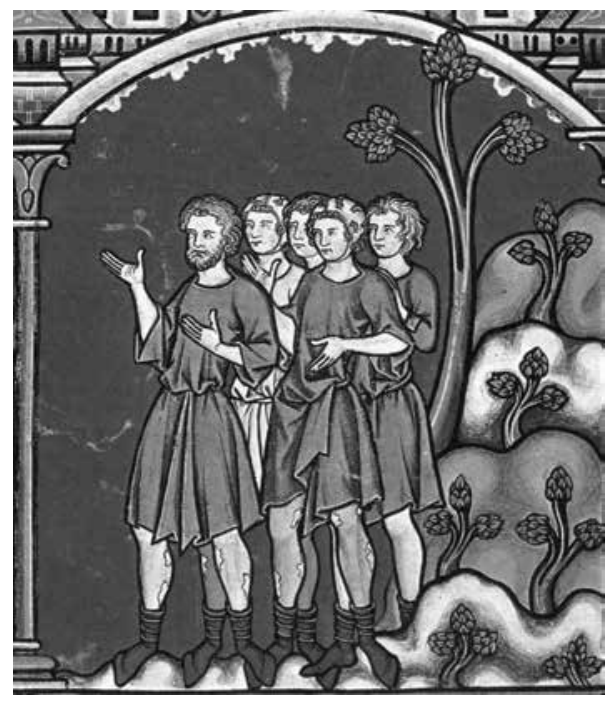

Obr. 6. Výjev z Křižácké bible, kolem 1250. Vyobrazení muži mají na nohou polovysokou obuv se zavazovaním pomocí tří řad řemínků. Podle The Morgan Library Museum, on-line.

Abb. 6. Szene aus der Kreuzfahrerbibel, um 1250. Die dargestellten Männer tragen Halbschuhe mit aus drei Riemenreihen bestehender Bindung. Nach The Morgan Library Museum, on-line. z této lokality jsou ve velice špatném stavu a žádná se nedochovala zcela kompletní. Tvarově jsou různorodé, a pokud je to možné určit (celkem v 5 př́ípadech), vyskytují se jak výrazně asymetrické, tak i spí̌e symetrické s nevýrazným (širokým) klenkem. Největši změřená podešev má na délku ca $270 \mathrm{~mm}$ a v dnešním číslování by šlo o dospělou velikost č. 41 až 42 . Ke spojení se svrškovými dílci bylo použito stehu vedeného jak ve směru rub/hrana, tak také ve směru rub/líc. Na některých podešvích jsou patrné drobné otvory v nártu, klenku a patě, které jsou pozůstatkem po prrituknutí $\mathrm{k}$ ševcovskému kopytu. I přes fakt, že pochází z dlouhého časového rozpětí 13. až 15. století a lze je poměrně dobře datovat, nevykazují výraznější chronologickou citlivost.

\subsubsection{Vyztužovací dílce}

Všechny zástupce $\mathrm{z}$ této kategorie jsme alespoň jednou popsali v předchozích kapitolách a na tomto místě se tak zmíníme pouze o jednom. Jde o tzv. podkroužek, tedy dílec používaný v oblasti zavazovacích otvorů (tab. IV, obr. 3). Tento má přibližně obdélný tvar o maximálních rozměrech $69 \times 30 \mathrm{~mm}$ s úzkým protáhlým výkrojkem uprostřed, který dílec rozděluje na dvě poloviny. V každé z nich lze napočítat čtyři drobné kulaté otvory sloužící k provlečení zavazovacích řemínků (tkaniček). Po obou delších stranách a ve spodní části jsou pak viditelné stopy po přišití ke svršku (stehy ve směru rub/rub) i spodkovým dílcům (rub/líc). Předmět je bohužel poškozen, zbylá (horní) část se nedochovala a nelze tak určit původní výšku artefaktu, a tedy i přibližnou výšku celé boty. Díky tomuto dílci lze v souboru identifikovat další typ obuvi, který se upevňoval k noze pomocí šněrovacích tkaniček uložených na boku (type 50 , podle Goubitz 2001, 175-177; obr. 5). Nález pochází z jímky označené jako s. j. 598, která je rámcově datována do 14. století.

\subsection{Ostatni}

Prvním zástupcem této skupiny je fragment pochvy o maximálních rozměrech $105 \times 35 \mathrm{~mm}$ (tab. IV, obr. 1). Vyrobena byla prostým přehnutím usně na jedné a sešitím na druhé straně. Po tomto úkonu se dochovaly dva poměrně dlouhé a úzké otvory. Celkově je předmět ve špatném 

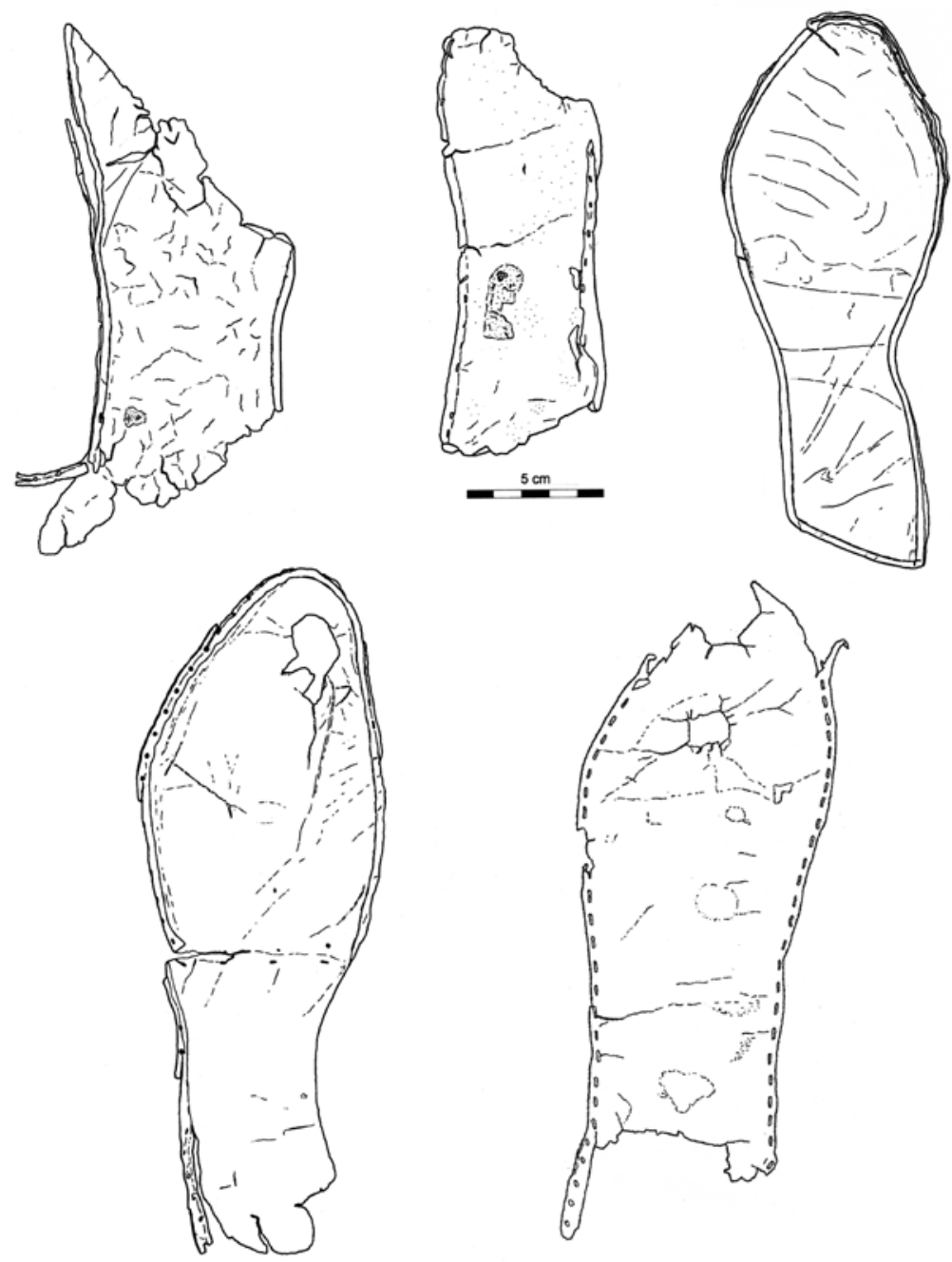

Tab. VII. Podešve. Kresba I. Ženožičková.

Taf. VII. Sohlen. Zeichnung I. Ženožičková.

stavu, a proto byl pravděpodobně také vyhozen. Nález pochází ze zásypu jímky, jejíž vznik je datován do roku 1441.

Druhým předmětem je drobný fragment opasku s dvěma řadami drobných ozdobných záseků o maximálních rozměrech $47 \times 28 \mathrm{~mm}$ (tab. IV, obr 2). Pochází z jímky datované do 70 . let 14. století.

Oba artefakty mají svou analogii např. v souboru pocházejícím ze zaniklého předhradí ve Veselí nad Moravou (Dejmal-Hoch 2013, 663, Tab. 5, 665, Tab. 4).

\section{Vyhodnocení souboru a závěr}

Předkládaný soubor pocházející ze zásypů zaniklých středověkých jímek tvoří z naprosté většiny obuv šitá tzv. obráceným způsobem. Použitá kůže, resp. useň je nejčastěji hovězí či 
telecí, v jednom př́padě byla identifikována skopovice či kozina, a to u svršku z dětské boty. Nutno však podotknout, že identifikace nebyla provedena u celého souboru, ale pouze na reprezentativním vzorku, který tvoří jádro tohoto příspěvku. Pomineme-li neurčitelné fragmenty, jde většinou pouze o jednotlivé dílce, jako jsou různé části svršků, podešve, okolky, vnitřní vyztužovací dílce, ozdobné lemůvky apod. V několika málo případech bylo možné přiřadit některé $\mathrm{z}$ nich $\mathrm{k}$ sobě a $\mathrm{v}$ jednom dokonce poskládat téměř kompletní půlpár v podobě nízkého stř̌evíce $\mathrm{s}$ páskem přes nárt. Celkově však jde o záměrně vyhozený odpad, což dokládá jak míra opotřebení, tak místo nálezu. Č́st lze dokonce považovat za odpad z ševcovské dílny, což indikují zejména výkrojky z nových, na první pohled dosud nepoužitých usní. I přes zmíněná fakta se v souboru podařilo identifikovat šest různých typů obuvi. Tato typologie, založená na celkovém tvaru a způsobu zapínání, vychází výhradně ze zahraničních souborů, pocházejících zejména ze severní a západní Evropy, kde má bádání o této problematice mnohaletou tradici (srov. např. Carlson on-line; Goubitz 2001; Grew-Neergaard 2010; Mould-Carlisle-Cameron 2003; Kowalska 2010; Schnack 1994; Swan 1995, 63; Volken 2014; Wywrot-Wyszkowska 2009 aj.). Jednotlivé analogie lze však nalézt i u nás. Běžný je zejména typ s jednou či více řadami zavazovacích řemínků (Hoch 2015, 45, Tab. 5; Dejmal-Hoch 2013, 658). Vhodným zdrojem informací se při absenci srovnávacího materiálu stávají také ikonografické prameny (např. Hřibová-Gřešák 2012, 124-134; Shromáždilová 2001, 53).

Celý soubor spadá do širokého časového rozpětí 13. až 15. století, přičemž díky dendrochronologii lze jednotlivé skupiny artefaktů poměrně přesně datovat. Obecně to bývá do značné míry problém, k jehož řešení však mohou časem přispět i samy artefakty. Každé spojení absolutních dat a vlastních nálezů nám totiž dává jedinečnou možnost komparace a zejména z tohoto hlediska je tak zkoumaný soubor více než př́ínosný.

\section{Zkratky}

SCD

Style and chronology diagram

\section{Literatura}

ALBRECHT, L.-ELBURG, R., 2014: Stielfel und Lersen als Bergmannsbekleidung aus dem späten 13. Jahrhundert, ArcheoMontan 2014, 229-241.

DEJMAL, M.-HOCH, A., 2013: Kožené artefakty z hradu ve Veselí nad Moravou - Lederartefakte von der Burg in Veselí nad Moravou (Wessely an der March), AH 38, 653-671.

FLODROVÁ, M., 2015: Nároží České a Jakubské ulice v Brně v první polovině 14. století. In: Archivum amicus historici est (Červená, R., ed.), 124-138. Brno.

GOUBITZ, O., 2001: Stepping through Times: Archaeological Footwear from Prehistoric Times until 1800. Zwolle.

GREW, F.-NEERGAARD, M., 2010: Shoes and Pattens. Medievals finds from excavations in London 2. London.

HOCH, A., 2015: Kožené artefakty z Jihlavy, Archeologické výzkumy na Vysočině 4/2013, 39-61.

HŘIBOVÁ, M.-GŘEŠÁK, V., 2012: Analýza gotické obuvi na malbách v kostele sv. Jakuba Většího ve Slavětíně nad Ohří. In: Obuv v historii: Sborník materiálů ze VI. mezinárodní konference, Zlín 12.14. ř́ína 2010, 124-134. Zlín.

JAN, L.-PROCHÁZKA, R., 2013: Vznik institucionálního města. In: Dějiny Brna 2 (Jan, L., ed.), $32-59$. Brno.

KOWALSKA, A. B., 2010: Wytwórczość skórzana we wczesnośredniowiecznym Szczecinie. Szczecin.

KRÁSA, J., 1990: České iluminované rukopisy 13./16. století. Praha.

MOULD, Q.-CARLISLE, I.-CAMERON, E., 2003: Craft, Industry and Everyday Life: Leather and Leatherworking in Anglo-Scandinavian and Medieval York. York.

PROCHÁZKA, R., 2000: Zrod středověkého města na př́kladu Brna (k otázce odrazu společenské změny v archeologických pramenech) - Entstehung der mittelalterlichen Stadt - Beispiel Brünn (Zur Frage der 
Widerspiegelung der Gesellschaftsveränderung in archäologischen Quellen). In: Brno a jeho region. Mediaevalia archaeologica 2 (Ježek, M., ed.), 7-158. Praha - Brno.

SHROMÁŽDILOVÁ, I., 2001: Kožedělná výroba ve středověkém Brně - Die Lederverarbeitung im mittelalterlichen Brünn, BMD 15, 33-61.

SCHNACK, K., 1994: Mittelalterliche Lederfunde aus Konstanz. Stuttgart.

SWANN, M. J., 1995: Historie módních stylů obouvání, západní Evropa. In: Obuv v historii: Sborník materiálů z I. mezinárodní konference, Zlín 19.-21. září 1994, 63. Zlín.

VIČAR, O., 1965: Místopis Brna v polovici 14. století, BMD 7, 242-283.

VOLKEN, M., 2014: Archaeological Footwear: Development of shoe patterns and styles from Prehistory till the 1600 s. Assen.

WYWROT-WYSZKOWSKA, B., 2009: Skórnictwo w lokacyjnym Kolobrzegu. XIII-XV wiek. Szczecin.

ZEMAN, F.-POTU゚ČEK, V., 1965: Technologie rukodílné výroby obuvi pro I. ročník odborných učilišt' a učňovských škol. Praha.

\section{Internetové zdroje}

Carson, I. M., 1996-2005: Footwear of the middle ages [on-line]. Dostupné z: http://www.personal.utulsa. edu/ marc-carlson/shoe/SHOEHOME.HTM, cit. 21. 3. 2015.

Hausbuch der Mendelschen Zwölfbruderstiftung, Band 1, folio 17 verso [on-line]. Dostupné z: http://www. nuernberger-hausbuecher.de/75-Amb-2-317-17-v, cit. 30. 3. 2015.

Hausbuch der Mendelschen Zwölfbruderstiftung, Band 1, folio 23 recto [on-line]. Dostupné z: http://www. nuernberger-hausbuecher.de/75-Amb-2-317-23-r, cit. 30. 3. 2015.

The Morgan Library Museum, The Crusader Bible, Manuscript, fol. 32v [on-line]. Dostupné z: http://www. themorgan.org/collection/crusader-bible/64, cit. 30. 3. 2015.

\section{Zusammenfassung}

\section{Artefakte aus Leder aus der Brünner Straße Česká}

Der vorliegende Beitrag beschäftigt sich mit Artefakten aus Leder, die aus den Verfüllungen von insgesamt sieben, bei einer auf mittelalterlichen Parzellen im Brünner Stadtzentrum durchgeführten Grabung entdeckten, verschwundenen Abwasserbecken stammen. In dem nicht ganz dreihundert Funde zählenden Komplex sind fast ausschließlich verschiedene Bestandteile von Schuhwerk vertreten, wie etwa Schäfte, Bodenteile und Versteifungsmaterial, Zierbordüren, Riemen, Verbindungsstreifen u.ä. es sind. In Ausnahmefällen ließen sich einige von ihnen einander zuordnen, in einem Fall sogar zu einem ursprünglichen Ganzen komplettierten, wodurch ein flacher Schuhtyp mit Ristriemen und Schnalle identifiziert werden konnte. Insgesamt gelang es, noch weitere vier Schuhtypen zu bestimmen, deren Analogien vorerst besonders im Ausland gefunden werden können. Den überwiegenden Teil bilden jedoch nicht identifizierte Fragmente, die sich häufig in einem sehr schlechten Erhaltungszustand befanden. Der gesamte Komplex besteht demnach aus absichtlich entsorgtem Abfall, wovon ein Teil wahrscheinlich direkt aus einer Schusterwerkstatt stammt. Mit Hilfe der Dendrochronologie können die Funde in die beträchtliche Zeitspanne zwischen erstem Viertel des 13. Jahrhunderts und Ende des 15. Jahrhunderts datiert werden.

Mgr. Aleš Hoch, Muzeum Vysočiny Jihlava, p. o., Masarykovo náměstí 55, 58601 Jihlava, Česká republika, hoch@muzeum.ji.cz

Mgr. Pavel Staněk, Archaia Brno, o.p. s., Bezručova 15, 60200 Brno, Česká republika, pstanek@archaiabrno.cz 
